\title{
UTJECAJ DEMOGRAFSKIH OBILJEŽJA POTROŠAČA NA PRIHVAĆENOST MARKETINGA OPĆEG DOBRA ${ }^{1}$
}

\section{THE INFLUENCE OF CONSUMER DEMOGRAPHICS ON THE ACCEPTANCE OF CAUSE RELATED MARKETING}

SAŽETAK: Rad pridonosi korpusu znanja iz područja marketinga općeg dobra, analizirajući utječu li demografska obilježja potrošača (dob, spol, razina primanja te stupanj obrazovanja) potrošača na prihvaćenost kampanja marketinga općeg dobra. Dosadašnja istraživanja su potvrdila da se percepcije i stavovi potrošača o prihvatljivosti, a time i uspješnost kampanja marketinga općeg dobra, razlikuju ovisno o njihovim demografskim obilježjima. U radu se istražuju percepcije ispitanika o primjerenosti primjene marketinga općeg dobra za rješavanje društvenih problema, percipirani utjecaj programa marketinga općeg dobra na odluku o kupnji te utjecaj demografskih obilježja na percepcije ispitanika. Istraživanje je provedeno na prigodnom uzorku 395 ispitanika različitih demografskih obilježja s područja Republike Hrvatske. Rezultati istraživanja pokazuju kako obilježja spola i dobi imaju značajan utjecaj na percepcije potrošača i prihvaćenost programa marketinga općeg dobra, dok se percepcije potrošača s obzirom na obilježja primanja i obrazovanja statistički značajno ne razlikuju.

KLJUČNE RIJEČI: marketing općeg dobra, demografska obilježja potrošača, dob, spol, primanja, obrazovanje

ABSTRACT: The paper contributes to the body of knowledge in the field of cause related marketing, by analyzing whether the demographic characteristics of consumers (age, gender, income level and level of education) affect the acceptance of cause related marketing campaigns. Research to date have confirmed that consumer perceptions and attitudes about acceptability, and thus the success of cause related marketing campaigns, differ depending

Prof. dr. sc. Dubravka Sinčić Ćorić, Sveučilište u Zagrebu, Ekonomski fakultet, Katedra za marketing, Trg J. F. Kennedyja 6, 10000 Zagreb, e-mail: dsincic@net.efzg.hr

** Jelena Tomić, mag. oec., e-mail: jelena.tomic.colic@gmail.com

1 U radu su korišteni podaci prikupljeni za potrebe diplomskoga rada Jelene Tomić, mag.oec., izrađenog pod mentorstvom prof. dr. sc. Dubravke Sinčić Ćorić. 
on their demographic characteristics. The paper investigates respondents 'perceptions of the appropriateness of the application of cause related marketing to solve social problems, the perceived impact of the cause related marketing program on the purchase decision and the impact of demographic characteristics on respondents' perceptions. The research was conducted on a sample of 395 respondents of different demographic characteristics from the Republic of Croatia. The results of the research show that gender and age have a significant impact on consumer perceptions and acceptance of the cause related od marketing program, while consumer perceptions with regard to income and level of education do not differ statistically significantly.

KEY WORDS: cause related marketing, consumer demographics, age, gender income, education

\section{UVOD}

Dvadeset i prvo stoljeće obilježeno je značajnim porastom konkurencije i osnaživanjem informiranih, zahtjevnih i društveno osjetljivih potrošača. Od poduzeća se očekuje izvrsnost i primjena visokih standarda u svim područjima djelovanja - od proizvoda, usluga i procesa do zaštite okoliša, ulaganja u zajednicu i poticanja pozitivnih društvenih promjena. Jedan od načina promjene društvene svijesti je marketing općeg dobra (engl. cause-related marketing).

Marketing općeg dobra predstavlja promicanje proizvoda, usluge, marke ili organizacije kroz uzajamno korisne odnose između profitnog i neprofitnog partnera (Berglind i Nakata, 2005.), pri čemu poduzeće veže svoje ime, marku ili uslugu s određenim dobrotvornim ciljem odnosno dobrotvornom organizacijom (Endacott, 2004.). Marketing općeg dobra se smatra "win-win-win" situacijom zato što donosi određene prednosti svim uključenim stranama (Adkins, 1999.) - proizvođaču, potrošaču i dobrotvornoj organizaciji. Međutim, postoje i određene kritike koje mogu dovesti do skepticizma potrošača prema aktivnostima marketinga općeg dobra. Kao najznačajnije se ističu sumnja u motive profitnog partnera, prebacivanje troška donacije na potrošače i shvaćanje marketinga općeg dobra kao eksploatacije neprofitnog partnera i cilja.

Istraživanja su pokazala kako marketing općeg dobra ima više korisnih učinaka: (1) utječe na odluku o kupnji (Adkins, 1999.; Chang, 2008.; Roy i Graeff, 2003.; Sinčić Ćorić i sur., 2011.; Webb i Mohr, 1998.), na način da potrošači odluče zamijeniti marku proizvoda koju inače koriste za marku proizvoda koja podržava određeni društveni cilj (Adkins, 1999.; Sinčić Ćorić i sur., 2011.), (2) vodi većoj lojalnosti potrošača (Adkins, 2007.; Kotler i Lee, 2009.; van den Brink i sur., 2006.) i (3) može imati utjecaja na cijenu koju su potrošači spremni platiti za proizvod (Barone i sur., 2000.; Meyer, 1999.; Subrahmanyan, 2004.).

Ovaj rad pridonosi istraživanju marketinga općeg dobra analizirajući koliko dob, spol, razina primanja te stupanj obrazovanja potrošača utječu na prihvaćenost kampanja marketinga općeg dobra. Dosadašnja istraživanja su potvrdila da se percepcije i stavovi potrošača o prihvatljivosti, a time i uspješnost kampanja marketinga općeg dobra, razlikuju ovisno o raznim čimbenicima poput: spola (Chéron i sur., 2012.; Cui i sur., 2003.; Ross i sur., 1992.; Moosmayer i Fuljahn, 2010.; Youn i Kim, 2008.), dobi (Barnes, 1992.; Cui i sur., 2003.; Cone, 2004.; Galan Ladero i sur., 2015.; Youn i Kim, 2008.), primanja potrošača (Barnes, 1992.; Cui i sur., 2003.; Hammad i sur., 2014.), razine obrazovanja (Mohr i sur., 2001.), iznosa donacije (Chang, 2008.; Dahl i Lavack, 1995.; Hajjat, 2003.; Sinčić Ćorić i sur., 
2011.), trajanja kampanje (Cheron i sur., 2012.; van den Brink i sur., 2006.; Varadarajan i Menon,1988.), povezanosti marke i dobrotvornoga cilja (Lichtenstein i sur., 2004.; Nan i Heo, 2007.; Pracejus i Olsen, 2004.), važnosti koju potrošači pridaju cilju (Farache i sur., 2008.; Lafferty, 1996.) i drugih.

Nastavno na izneseno, cilj rada je utvrditi kako različiti čimbenici (dob, spol, razina obrazovanja, razina primanja, trajanje kampanje te iznos donacije) utječu na percepcije potrošača o marketingu općeg dobra. Stoga se u nastavku rada najprije iznosi pregled dosadašnjih istraživanja o utjecaju demografskih obilježja potrošača (spol, dob, stupanj obrazovanja i razina prihoda) na prihvaćenost marketinga općeg dobra. Nakon toga slijedi opis metodologije i prikaz rezultata. Rad završava raspravom i zaključcima.

\section{PREGLED LITERATURE O UTJECAJU DEMOGRAFSKIH OBILJEŽJA POTROŠAČA NA PRIHVAĆENOST MARKETINGA OPĆEG DOBRA}

\subsection{Utjecaj spola potrošača na prihvaćenost marketinga općeg dobra}

Moosmayer i Fuljahn (2010.) ističu kako postoje razlike u vrijednostima, ponašanjima i stavovima između muškaraca i žena koje se baziraju na različitim društveno nametnutim rodnim ulogama. U tom smislu, istraživanja su pokazala kako muškarci općenito manje doniraju od žena (Harvey, 1990.; Jones i Posnett, 1991.) odnosno kako žene preferiraju donirati s ciljem pomaganja drugima, dok muškarci više reagiraju na komunikaciju koja naglašava i osobne koristi za njih, poput na primjer poreznih olakšica prilikom donacije (Brunel i Nelson, 2000.).

Razlike ovisno o spolu ispitanika postoje i kada je riječ o marketingu općeg dobra. Istraživanja su pokazala kako žene imaju (1) veću tendenciju sudjelovanja u programima marketinga općeg dobra (Chéron i sur., 2012.; Cui i sur., 2003.; Moosmayer i Fuljahn, 2010.; Ross i sur., 1992.; Youn i Kim, 2008.), (2) pozitivnije stavove prema poduzeću i neprofitnoj organizaciji uključenoj u marketing općeg dobra (Chéron i sur., 2012.; Cui i sur., 2003.; Ross i sur., 1992.; Youn i Kim, 2008.) te (3) veću sklonost platiti veći iznos za proizvod koji pridonosi dobrotvornom cilju, od muškaraca (Chéron i sur., 2012.).

S druge strane, Galan Landero i sur. (2015.) nisu potvrdili utjecaj spola na stavove prema marketingu općeg dobra.

Na temelju prethodnih istraživanja, u ovom istraživanju pretpostavlja se da će žene iskazati veću prihvaćenost marketinga općeg dobra u odnosu na muškarce.

\subsection{Utjecaj dobi potrošača na prihvaćenost marketinga općeg dobra}

Istraživanja su pokazala kako dob utječe na stavove prema filantropskim organizacijama te na prirodu i opseg doniranja (Bennett, 2003.; Supphellen i Nelson, 2001.) te na stavove odnosno prihvaćenost kampanja marketinga općeg dobra (Barnes, 1992.; Cui i sur., 2003.; Galan Ladero i sur., 2015.; Youn i Kim, 2008.). Barnes (1992.) je utvrdio kako su ispitanici mlađi od 35 godina imali najpozitivniji stav prema marketingu općeg dobra, ispitanici u dobnoj skupini od 36 do 50 godina su bili relativno indiferentni prema njemu, dok 
su se ispitanici stariji od 56 godina imali u određenoj mjeri negativan stav. Slično navode i Galan Ladero i sur. (2015.). Youn i Kim (2008.) ističu da su mlađi ispitanici otvoreniji prema marketingu općeg dobra u odnosu na starije te spremniji kupiti, odnosno razmotriti proizvode povezane s marketingom općeg dobra prilikom njihove odluke o kupnji (Cui i sur., 2013.; Galan Ladero i sur., 2015.; Youn i Kim, 2008.). Cone (2004.) također navodi kako je veća vjerojatnost da će mlađi potrošači prepoznati odnosno razlikovati proizvode koji su povezani s određenim društvenim ciljem, a istraživanje koje su proveli Kim i Johnson (2013.) potvrđuje da su pojedinci koji će najvjerojatnije kupiti društveno odgovoran proizvod oni iz skupine mlađih potrošača.

Navedeno sugerira da će i rezultati ovog istraživanja potvrditi kako mlađi potrošači iskazuju veću prihvaćenost marketinga općeg dobra.

\subsection{Utjecaj primanja potrošača na prihvaćenost marketinga općeg dobra}

Vanhamme i sur. (2012.) navode kako razina primanja pojedinca može imati utjecaja na njegovu reakciju prema marketingu općeg dobra. Istraživanja su pokazala kako su potrošači sa srednjom do višom razinom primanja više društveno osviješteni (Webb i Mohr, 1998.) te da potrošači s višom razinom primanja imaju pozitivnije stavove prema poduzećima koja sudjeluju u programima marketinga općeg dobra (Barnes, 1992.; Hammad i sur., 2014.). Istraživanjem stavova generacije Y prema marketingu općeg dobra, Cui i sur. (2003.) su promatrali i primanja roditelja ispitanika (istraživanje je provedeno nad studentima te je prosječna dob ispitanika bila 21 godinu) te su utvrdili kako su skupine sa srednjim do višim primanjima najpodložnije utjecaju kampanja marketinga općeg dobra, odnosno kako postoji povezanost između primanja roditelja i odgovora studenata vezanim za marketing općeg dobra. Nadalje, učinkovitost programa marketinga općeg dobra se povećava sa stabilnošću potrošačevih primanja (Guerreiro i sur., 2015.). Ti rezultati su u skladu i s činjenicom da, općenito, potrošači koji imaju veća primanja i više doniraju u dobrotvorne svrhe (Bennett, 2003.; Schlegelmilch i sur., 1997.). Međutim, postoji nekonzistentnost između rezultata istraživanja. Tako Chaney i Dolli (2001.) i Lerro i sur. (2019.) nisu utvrdili korelaciju između razine primanja i stavova potrošača prema marketingu općeg dobra.

S obzirom na nalaze prethodnih istraživanja, pretpostavlja se da će i u ovom istraživanju potrošači viših razina primanja iskazati veću prihvaćenost marketinga općeg dobra.

\subsection{Utjecaj obrazovanja potrošača na prihvaćenost marketinga općeg dobra}

Mali broj istraživanja povezanosti razine obrazovanja i stavova prema marketingu općeg dobra pokazuju kako razina obrazovanja utječe na širok opseg društvenog odnosno društveno odgovornog ponašanja potrošača (Penner i sur., 2005.) što bi moglo utjecati i na njihovu percepciju marketinga općeg dobra (Mohr i sur., 2001.) te da su obrazovaniji potrošači skloniji donirati novac u dobrotvorne svrhe (Bennett, 2003.; Chrenka i sur., 2003.). Međutim, Youn i Kim (2008.) nisu pronašli povezanost između razine obrazovanja i prihvaćenosti kampanja marketinga općeg dobra. 
Sukladno iznesenome, u ovom istraživanju pretpostavlja se da razina obrazovanja nema utjecaj na prihvaćenost marketinga općeg dobra.

\section{ISTRAŽIVANJE UTJECAJA DEMOGRAFSKIH OBILJEŽJA POTROŠAČA NA USPJEŠNOST MARKETINGA OPĆEG DOBRA}

\subsection{Ciljevi istraživanja}

Ciljevi empirijskog dijela istraživanja su (1) utvrditi percepcije ispitanika o primjerenosti primjene marketinga općeg dobra za rješavanje društvenih problema, (2) utvrditi percipirani utjecaj programa marketinga općeg dobra na odluku o kupnji te (3) utvrditi kako različiti čimbenici (dob, spol, razina obrazovanja, razina primanja, trajanje kampanje te iznos donacije) utječu na percepcije ispitanika.

\subsection{Uzorak istraživanja}

Istraživanje je provedeno na prigodnom uzorku od 395 ispitanika različitih demografskih obilježja s područja Republike Hrvatske. Pregled strukture uzorka nalazi se u Tablici 1.

Tablica 1. Struktura uzorka

\begin{tabular}{|c|c|c|c|}
\hline $\begin{array}{c}\text { Demografska } \\
\text { karakteristika }\end{array}$ & Obilježje & $\begin{array}{c}\text { Apsolutni broj } \\
\text { ispitanika }\end{array}$ & Postotak \\
\hline \multirow{2}{*}{ Spol } & Muško & 100 & $25,30 \%$ \\
\hline & Žensko & 295 & $74.70 \%$ \\
\hline \multirow{6}{*}{ Dob } & $18-24$ & 180 & $45,57 \%$ \\
\hline & $25-35$ & 138 & $34,94 \%$ \\
\hline & $36-45$ & 35 & $8,86 \%$ \\
\hline & $46-55$ & 10 & $2,53 \%$ \\
\hline & $56-65$ & 20 & $5,06 \%$ \\
\hline & više od 65 & 12 & $3,04 \%$ \\
\hline \multirow{6}{*}{ Obrazovanje } & Osnovna škola & 1 & $0,25 \%$ \\
\hline & Srednja škola & 130 & $32,91 \%$ \\
\hline & Stručni studij & 39 & $9,87 \%$ \\
\hline & Preddiplomski studij & 106 & $26,84 \%$ \\
\hline & Diplomski studij & 113 & $28,61 \%$ \\
\hline & Doktorat & 6 & $1,52 \%$ \\
\hline \multirow{7}{*}{ Razina primanja } & bez primanja & 89 & $22,53 \%$ \\
\hline & do $1500 \mathrm{kn}$ & 44 & $11,14 \%$ \\
\hline & $1501-3500 \mathrm{kn}$ & 38 & $9,62 \%$ \\
\hline & $3501-6500 \mathrm{kn}$ & 93 & $23,54 \%$ \\
\hline & $6501-9500 \mathrm{kn}$ & 57 & $14,43 \%$ \\
\hline & više od $9500 \mathrm{kn}$ & 28 & $7,09 \%$ \\
\hline & Ne želim odgovoriti & 46 & $11,65 \%$ \\
\hline
\end{tabular}

Izvor: istraživanje 


\subsection{Metodologija istraživanja}

Primarni podaci prikupljeni su metodom ispitivanja uz pomoć anketnog upitnika. Upitnik je napravljen i prilagođen prema prethodnim istraživanjima koje su proveli Ross i sur. (1992.), Webb i Mohr (1998.), Sinčić Ćorić i Kurnoga (2009.) i Galan Ladero i sur. (2015.). Upitnik je distribuiran u razdoblju od 14. do 19. rujna 2020. godine online, putem društvene mreže Facebook te direktno putem elektroničke pošte i aplikacije WhatsApp.

Upitnik sadrži 25 pitanja podijeljena u tri skupine. Prva skupina sadrži 16 tvrdnji kojima je cilj istražiti percepcije ispitanika prema primjerenosti primjene marketinga općeg dobra za rješavanje društvenih problema, percepcije prema poduzećima i neprofitnim organizacijama koje sudjeluju u takvim programima te percipiranom utjecaju programa marketinga općeg dobra na kulturu doniranja i svijest o društvenom problemu. Druga skupina se sastoji od 5 pitanja kojima se istražuju percepcije ispitanika o utjecaju marketinga općeg dobra na odluku o kupnji. Treća skupina sadrži 4 pitanja o demografskim obilježjima ispitanika, odnosno dobi, spolu, razini primanja te postignutom stupnju obrazovanja. Pitanja su zatvorenog tipa te je korištena 5-stupanjska Likertova ljestvica prema ispitanici označuju stupanj slaganja odnosno neslaganja s datom tvrdnjom, gdje 1 označava "uopće se ne slažem", a 5 "u potpunosti se slažem".

\subsection{Rezultati i rasprava}

\subsubsection{Percepcije potrošača o marketingu općeg dobra}

Pitanja vezana za percepcije potrošača o marketingu općeg dobra su grupirana po tvrdnjama. Prva skupina pitanja odnosi se na percepciju ispitanika prema marketingu općeg dobra općenito te prikladnosti njegove primjene za rješavanje društvenih problema odnosno doprinos društvu. Ne promatrajući ostale čimbenike, ispitanici se u prosjeku najviše slažu s tvrdnjama kako je marketing općeg dobra dobar način prikupljanja sredstava za neki dobrotvorni cilj, dok je visoka razina slaganja i s tvrdnjom kako kupnjom proizvoda koji doprinosi nekom dobrotvornom cilju čine dobro. Rezultati sugeriraju kako potrošači imaju općenito pozitivne percepcije o marketingu općeg dobra, unatoč tome što izražavaju relativno pozitivnu razinu slaganja s tvrdnjom da bi radije donirali direktno nekom dobrotvornom cilju nego kupili proizvod koji doprinosi dobrotvornom cilju. Pregled rezultata ove skupine tvrdnji nalazi se u Tablici 2. 
Tablica 2. Skupni pregled rezultata istraživanja o percepcijama potrošača prema marketingu općeg dobra prva skupina tvrdnji $(\mathrm{n}=395)$

\begin{tabular}{|c|c|c|c|c|}
\hline Tvrdnja & $\begin{array}{l}\text { Prosječna } \\
\text { vrijednost }\end{array}$ & $\begin{array}{c}\text { Apsolutna } \\
\text { frekvencija } \\
\text { odgovora ,u } \\
\text { potpunosti se } \\
\text { slažem“6 } \\
\end{array}$ & $\begin{array}{c}\text { Apsolutna } \\
\text { frekvencija } \\
\text { odgovora } \\
\text { "uopće se ne } \\
\text { slažem“" }\end{array}$ & $\begin{array}{l}\text { Oznaka } \\
\text { tvrdnje }\end{array}$ \\
\hline $\begin{array}{l}\text { Marketing općeg dobra je } \\
\text { dobar način prikupljanja } \\
\text { sredstava za neki dobrotvorni } \\
\text { cilj. }\end{array}$ & 4,17 & 187 & 7 & $\begin{array}{c}\text { „Tvrdnja } \\
1 “\end{array}$ \\
\hline $\begin{array}{l}\text { Kupnjom proizvoda } \\
\text { koji doprinose nekom } \\
\text { dobrotvornom cilju činim } \\
\text { dobro. }\end{array}$ & 4,12 & 186 & 14 & $\begin{array}{c}\text { "Tvrdnja } \\
\text { 2“ }\end{array}$ \\
\hline $\begin{array}{l}\text { Marketing općeg dobra pomaže } \\
\text { povećati svijest o nekom } \\
\text { društvenom problemu. }\end{array}$ & 3,84 & 126 & 12 & $\begin{array}{c}\text { "Tvrdnja } \\
4 \times\end{array}$ \\
\hline $\begin{array}{l}\text { Marketing općeg dobra je } \\
\text { odličan način za rješavanje } \\
\text { društvenih problema. }\end{array}$ & 3,05 & 56 & 47 & $\begin{array}{c}\text { „Tvrdnja } \\
5 “\end{array}$ \\
\hline $\begin{array}{l}\text { Smatram kako marketing } \\
\text { općeg dobra promiče kulturu } \\
\text { doniranja i društveno korisnog } \\
\text { ponašanja }\end{array}$ & 3,61 & 88 & 25 & $\begin{array}{c}\text { „Tvrdnja } \\
7 “\end{array}$ \\
\hline $\begin{array}{l}\text { Radije ću direktno donirati } \\
\text { neprofitnoj organizaciji nego } \\
\text { kupiti proizvod koji doprinosi } \\
\text { dobrotvornom cilju. }\end{array}$ & 3,25 & 86 & 36 & $\begin{array}{c}\text { „Tvrdnja } \\
16^{“}\end{array}$ \\
\hline
\end{tabular}

Izvor: istraživanje

Kako bi se otkrile potencijalne statistički značajne razlike između odgovora muških i ženskih ispitanika proveden je t-test, koji je ukazao da postoje značajne statističke razlike između muških i ženskih ispitanika prema većini tvrdnji. Žene izražavaju prosječno veću razinu slaganja s tvrdnjama 1, 2, 4, 5 i 7 (Tablica 3.), što je u skladu s prethodnim istraživanjima (Chéron i sur., 2012.; Moosmayer i Fuljahn, 2010.; Ross i sur., 1992.), kao i polaznom pretpostavkom ovog istraživanja. 
Tablica 3. Deskriptivna statistika i t-test o statistički značajnim razlikama među ispitanicima istraživanju ovisno o spolu - prva skupina tvrdnji $(\mathrm{n}=395)$

\begin{tabular}{|c|c|c|c|c|c|c|c|}
\hline \multicolumn{2}{|l|}{ Tvrdnja/Spol } & \multirow{2}{*}{$\begin{array}{c}\mathbf{N} \\
100\end{array}$} & \multirow{2}{*}{$\begin{array}{l}\text { Mean } \\
3,77\end{array}$} & \multirow{2}{*}{$\begin{array}{c}\text { Sd } \\
1,072\end{array}$} & \multirow{2}{*}{$\begin{array}{l}\text { Std. } \\
\text { Error } \\
\text { Mean } \\
0,107\end{array}$} & $t$ & $p$ \\
\hline Marketing općeg dobra je dobar & Muško & & & & & \multirow[b]{2}{*}{$-4,98374$} & \multirow[b]{2}{*}{$<0,05$} \\
\hline $\begin{array}{l}\text { način prikupljanja sredstava za neki } \\
\text { dobrotvorni cilj. }\end{array}$ & Žensko & 295 & 4,31 & 0,882 & 0,051 & & \\
\hline \multirow{2}{*}{$\begin{array}{l}\text { Kupnjom proizvoda koji doprinose } \\
\text { nekom dobrotvornom cilju činim } \\
\text { dobro. }\end{array}$} & Muško & 100 & 3,72 & 1,164 & 0,116 & \multirow[b]{2}{*}{$-4,60531$} & \multirow[b]{2}{*}{$<0,05$} \\
\hline & Žensko & 295 & 4,26 & 0,960 & 0,056 & & \\
\hline \multirow{2}{*}{$\begin{array}{l}\text { Marketing općeg dobra pomaže } \\
\text { povećati svijest o nekom } \\
\text { društvenom problemu. }\end{array}$} & Muško & 100 & 3,46 & 1,096 & 0,110 & \multirow[b]{2}{*}{$-4,25122$} & \multirow[b]{2}{*}{$<0,05$} \\
\hline & Žensko & 295 & 3,97 & 1,015 & 0,059 & & \\
\hline \multirow{2}{*}{$\begin{array}{l}\text { Marketing općeg dobra je odličan } \\
\text { način za rješavanje društvenih } \\
\text { problema. }\end{array}$} & Muško & 100 & 2,61 & 1,205 & 0,121 & \multirow[b]{2}{*}{$-4,33775$} & \multirow[b]{2}{*}{$<0,05$} \\
\hline & Žensko & 295 & 3,20 & 1,165 & 0,068 & & \\
\hline \multirow{2}{*}{$\begin{array}{l}\text { Smatram kako marketing općeg } \\
\text { dobra promiče kulturu doniranja i } \\
\text { društveno korisnog ponašanja }\end{array}$} & Muško & 100 & 3,20 & 1,101 & 0,110 & \multirow[b]{2}{*}{$-4,37025$} & \multirow[b]{2}{*}{$<0,05$} \\
\hline & Žensko & 295 & 3,75 & 1,081 & 0,063 & & \\
\hline \multirow{2}{*}{$\begin{array}{l}\text { Radije ću direktno donirati } \\
\text { neprofitnoj organizaciji nego } \\
\text { kupiti proizvod koji doprinosi } \\
\text { dobrotvornom cilju. }\end{array}$} & Muško & 100 & 3,42 & 1,216 & 0,122 & \multirow[b]{2}{*}{1,629331} & \multirow[b]{2}{*}{$>0,05$} \\
\hline & Žensko & 295 & 3,19 & 1,246 & 0,073 & & \\
\hline
\end{tabular}

Izvor: istraživanje

Kako bi se promatrane tvrdnje usporedile prema više modaliteta, odnosno kako bi se utvrdile eventualne statistički značajne razlike među promatranim tvrdnjama ovisno o dobi, obrazovanju te razini primanja, proveden je niz F-testova. Rezultati pokazuju značajne razlike ovisno o dobi ispitanika za tvrdnje 1,2, 4, 5 i 7, dok kod tvrdnje 16 ne postoje statistički značajne razlike ovisno o dobi ispitanika (Tablica 4). 
D. Sinčić Ć́rić, J. Tomić: Utjecaj demografskih obilježja potrošača na prihvaćenost marketinga...

Tablica 4. Deskriptivna statistika i testiranje potencijalnih statistički značajnih razlika ovisno o dobi ispitanika - prva skupina tvrdnji $(\mathrm{n}=395)$

\begin{tabular}{|c|c|c|c|c|c|c|c|}
\hline \multicolumn{2}{|c|}{ Tvrdnja/dob } & $\mathbf{N}$ & Mean & $\begin{array}{c}\text { Std. } \\
\text { Deviation }\end{array}$ & $\begin{array}{c}\text { Std. } \\
\text { Error }\end{array}$ & $F$ & $p$ \\
\hline \multirow{6}{*}{$\begin{array}{l}\text { Marketing općeg } \\
\text { dobra je dobar } \\
\text { način prikupljanja } \\
\text { sredstava za neki } \\
\text { dobrotvorni cilj. }\end{array}$} & $18-24$ & 180 & 4,19 & 0,916 & 0,068 & \multirow{6}{*}{3,968} & \multirow{6}{*}{$<0,05$} \\
\hline & $25-35$ & 138 & 4,28 & 0,888 & 0,076 & & \\
\hline & $36-45$ & 35 & 3,69 & 1,255 & 0,212 & & \\
\hline & $46-55$ & 10 & 4,10 & 0,876 & 0,277 & & \\
\hline & $56-65$ & 20 & 3,75 & 1,020 & 0,228 & & \\
\hline & više od 65 & 12 & 4,75 & 0,866 & 0,250 & & \\
\hline \multirow{6}{*}{$\begin{array}{c}\text { Kupnjom } \\
\text { proizvoda koji } \\
\text { doprinose nekom } \\
\text { dobrotvornom cilju } \\
\text { činim dobro. }\end{array}$} & $18-24$ & 180 & 4,16 & 1,020 & 0,076 & \multirow{6}{*}{3,367} & \multirow{6}{*}{$<0,05$} \\
\hline & $25-35$ & 138 & 4,16 & 1,041 & 0,089 & & \\
\hline & $36-45$ & 35 & 3,69 & 1,132 & 0,191 & & \\
\hline & $46-55$ & 10 & 4,60 & 0,516 & 0,163 & & \\
\hline & $56-65$ & 20 & 3,70 & 1,031 & 0,231 & & \\
\hline & više od 65 & 12 & 4,75 & 0,866 & 0,250 & & \\
\hline \multirow{6}{*}{$\begin{array}{l}\text { Marketing općeg } \\
\text { dobra pomaže } \\
\text { povećati svijest o } \\
\text { nekom društvenom } \\
\text { problemu. }\end{array}$} & $18-24$ & 180 & 3,82 & 1,053 & 0,078 & \multirow{6}{*}{2,715} & \multirow{6}{*}{$<0,05$} \\
\hline & $25-35$ & 138 & 3,99 & 0,989 & 0,084 & & \\
\hline & $36-45$ & 35 & 3,46 & 1,146 & 0,194 & & \\
\hline & $46-55$ & 10 & 4,10 & 0,876 & 0,277 & & \\
\hline & $56-65$ & 20 & 3,35 & 1,226 & 0,274 & & \\
\hline & više od 65 & 12 & 4,17 & 1,115 & 0,322 & & \\
\hline \multirow{6}{*}{$\begin{array}{c}\text { Marketing općeg } \\
\text { dobra je odličan } \\
\text { način za rješavanje } \\
\text { društvenih } \\
\text { problema. }\end{array}$} & $18-24$ & 180 & 3,14 & 1,196 & 0,089 & \multirow{6}{*}{2,726} & \multirow{6}{*}{$<0,05$} \\
\hline & $25-35$ & 138 & 3,17 & 1,131 & 0,096 & & \\
\hline & $36-45$ & 35 & 2,60 & 1,218 & 0,206 & & \\
\hline & $46-55$ & 10 & 3,00 & 1,414 & 0,447 & & \\
\hline & $56-65$ & 20 & 2,50 & 1,277 & 0,286 & & \\
\hline & više od 65 & 12 & 2,58 & 1,311 & 0,379 & & \\
\hline \multirow{6}{*}{$\begin{array}{c}\text { Smatram kako } \\
\text { marketing općeg } \\
\text { dobra promiče } \\
\text { kulturu doniranja i } \\
\text { društveno korisnog } \\
\text { ponašanja }\end{array}$} & $18-24$ & 180 & 3,53 & 1,140 & 0,085 & \multirow{6}{*}{3,388} & \multirow{6}{*}{$<0,05$} \\
\hline & $25-35$ & 138 & 3,75 & 0,997 & 0,085 & & \\
\hline & $36-45$ & 35 & 3,11 & 1,345 & 0,227 & & \\
\hline & $46-55$ & 10 & 3,70 & 1,059 & 0,335 & & \\
\hline & $56-65$ & 20 & 3,70 & 0,979 & 0,219 & & \\
\hline & više od 65 & 12 & 4,42 & 0,793 & 0,229 & & \\
\hline \multirow{6}{*}{$\begin{array}{c}\text { Radije ću direktno } \\
\text { donirati neprofitnoj } \\
\text { organizaciji nego } \\
\text { kupiti proizvod } \\
\text { koji doprinosi } \\
\text { dobrotvornom } \\
\text { cilju. }\end{array}$} & 18-24 & 180 & 3,32 & 1,185 & 0,088 & \multirow{6}{*}{0,821} & \multirow{6}{*}{$>0,05$} \\
\hline & $25-35$ & 138 & 3,25 & 1,244 & 0,106 & & \\
\hline & $36-45$ & 35 & 2,94 & 1,235 & 0,209 & & \\
\hline & 46-55 & 10 & 3,30 & 1,160 & 0,367 & & \\
\hline & 56-65 & 20 & 3,25 & 1,446 & 0,323 & & \\
\hline & više od 65 & 12 & 2,83 & 1,749 & 0,505 & & \\
\hline
\end{tabular}

Izvor: istraživanje 
Promatrajući dob, najveću razinu slaganja s tvrdnjama 1, 2, 4 i 7 u prosjeku se može pronaći kod ispitanika koji su stariji od 65 godina. Navedeno sugerira kako ta skupina ima najpozitivnije percepcije prema marketingu općeg dobra općenito. Najveću razinu slaganja s tvrdnjom 5 je moguće pronaći kod dobne skupine od 25 do 35 godina, a odmah iza sa razinom slaganja slijedi dobna skupina od 18 do 24 godina, odnosno, vidljivo je da mlađi ispitanici izražavaju najveću razinu slaganja s tvrdnjom da je marketing općeg dobra odličan način za rješavanje društvenih problema.

Navedeni rezultati nisu u potpunosti u skladu s prethodnim istraživanjima koja su pokazala kako su stariji potrošači manje otvoreni prema marketingu općeg dobra (Galan Ladero i sur., 2015.; Youn i Kim, 2008.). Također, ne potkrjepljuju polaznu pretpostavku ovog istraživanja, koja sugerira da će mlađi potrošači iskazivati veću prihvaćenost marketinga općeg dobra.

Prosječno se najniža razina slaganja može pronaći kod dobne skupine 36-45 godina, što je sukladno nalazima prijašnjih istraživanja (Barnes, 1992.; Galan Ladero i sur., 2015.).

Razina primanja ispitanika, kao ni njihova obrazovna razina nisu potvrdili postojanje statistički značajnih razlika u odgovorima ispitanika. Polazna pretpostavka ovog istraživanja - da će razina primanja utjecati na prihvaćenost marketinga općeg dobra - ovim nalazima nije potvrđena. S druge strane, potvrđeno je da razina obrazovanja potrošača ne utječe na njihovu prihvaćenost marketinga općeg dobra.

Drugom skupinom tvrdnji provjeravale su se percepcije potrošača o marketingu općeg dobra koje su povezane s poduzećem. Rezultati prikazuju kako su potrošači, bez razmatranja njihovih demografskih obilježja, iskazali najveću razinu slaganja s tvrdnjom da imaju pozitivno mišljenje o poduzećima koja sudjeluju u marketingu općeg dobra. Relativno visoka razina slaganja postoji i kod tvrdnje da ta poduzeća doprinose dobrobiti zajednice. Nadalje, ispitanici se uglavnom slažu i s tvrdnjama da marketing općeg dobra doprinosi više poduzeću nego neprofitnoj organizaciji, kako poduzeća žele iskoristiti neki dobrotvorni cilj, a ne pomoći mu te kako bi poduzeća trebala direktno donirati neprofitnim organizacijama. Također, ispitanici iskazuju određenu razinu neslaganja s tvrdnjom kako marketing općeg dobra nije dobar način da poduzeće doprinese nekom dobrotvornom cilju. Navedeni rezultati sugeriraju relativno pozitivne percepcije ispitanika prema poduzećima koja sudjeluju u marketingu općeg dobra (Tablica 5). 
Tablica 5. Grupni pregled rezultata istraživanja o percepcijama potrošača prema marketingu općeg dobra druga skupina tvrdnji $(\mathrm{n}=395)$

\begin{tabular}{|c|c|c|c|c|}
\hline Tvrdnja & $\begin{array}{l}\text { Prosječna } \\
\text { vrijednost }\end{array}$ & \begin{tabular}{|c|} 
Apsolutna \\
frekvencija \\
odgovora ,u \\
potpunosti se \\
slažem"6 \\
\end{tabular} & \begin{tabular}{|c|} 
Apsolutna \\
frekvencija \\
odgovora \\
"uopće se ne \\
slažem" \\
\end{tabular} & $\begin{array}{l}\text { Oznaka } \\
\text { tvrdnje }\end{array}$ \\
\hline $\begin{array}{l}\text { Marketing općeg dobra je } \\
\text { samo način dodatne promocije } \\
\text { poduzeća. }\end{array}$ & 3,73 & 98 & 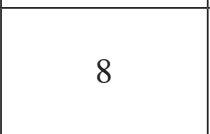 & Tvrdnja 3 \\
\hline $\begin{array}{l}\text { Smatram kako marketing } \\
\text { općeg dobra donosi više koristi } \\
\text { poduzećima nego neprofitnom } \\
\text { partneru. }\end{array}$ & 3,62 & 102 & 15 & Tvrdnja 6 \\
\hline $\begin{array}{l}\text { Imam pozitivno mišljenje o } \\
\text { poduzećima koja sudjeluju u } \\
\text { marketingu općeg dobra. }\end{array}$ & 3,91 & 129 & 5 & Tvrdnja 9 \\
\hline $\begin{array}{l}\text { Poduzeća koja sudjeluju } \\
\text { u marketingu općeg dobra } \\
\text { doprinose dobrobiti zajednice. }\end{array}$ & 3,80 & 114 & 14 & $\begin{array}{c}\text { Tvrdnja } \\
10\end{array}$ \\
\hline $\begin{array}{l}\text { Poduzeća koja sudjeluju u } \\
\text { marketingu općeg dobra žele } \\
\text { pomoći nekom dobrotvornom } \\
\text { cilju, a ne iskoristiti ga za } \\
\text { povećanje prodaje. }\end{array}$ & 2,84 & 32 & 47 & $\begin{array}{l}\text { Tvrdnja } \\
11\end{array}$ \\
\hline $\begin{array}{l}\text { Marketingom općeg dobra } \\
\text { poduzeća samo prebacuju trošak } \\
\text { doniranja na potrošača. }\end{array}$ & 3,27 & 62 & 23 & $\begin{array}{l}\text { Tvrdnja } \\
12\end{array}$ \\
\hline $\begin{array}{l}\text { Poduzeća koja sudjeluju u } \\
\text { marketingu općeg dobra ne } \\
\text { ponašaju se društveno odgovorno } \\
\text { - to je samo dodatni način da } \\
\text { povećaju svoju prodaju i profite. }\end{array}$ & 2,93 & 38 & 46 & $\begin{array}{c}\text { Tvrdnja } \\
13\end{array}$ \\
\hline $\begin{array}{l}\text { Marketing općeg dobra nije dobar } \\
\text { način da poduzeće doprinese } \\
\text { nekom neprofitnom cilju. }\end{array}$ & 2,50 & 23 & 84 & $\begin{array}{c}\text { Tvrdnja } \\
15\end{array}$ \\
\hline $\begin{array}{l}\text { Smatram kako marketing općeg } \\
\text { dobra ne pridonosi dovoljno } \\
\text { ostvarivanju neprofitnog cilja. }\end{array}$ & 3,16 & 55 & 30 & Tvrdnja 8 \\
\hline $\begin{array}{l}\text { Smatram kako bi poduzeća } \\
\text { trebala direktno donirati } \\
\text { neprofitnim organizacijama, a ne } \\
\text { koristiti kampanje marketinga } \\
\text { općeg dobra }\end{array}$ & 3,48 & 86 & 24 & $\begin{array}{c}\text { Tvrdnja } \\
14\end{array}$ \\
\hline
\end{tabular}

Izvor: istraživanje 
Rezultati t-testa potvrdili su da postoje značajne statističke razlike između muških i ženskih ispitanika prema tvrdnji 9, 10,11 i 8, dok kod tvrdnji 3, 6, 12, 13, 15 i 14 ne postoje statistički značajne razlike ovisno o spolu (Tablica 6). Žene iskazuju pozitivniju percepciju prema poduzećima koja sudjeluju u marketingu općeg dobra, odnosno iskazuju veće slaganje s tvrdnjom da poduzeća koja sudjeluju u marketingu općeg dobra doprinose dobrobiti zajednice, od muških ispitanika. S druge strane, muški ispitanici više percipiraju kako marketing općeg dobra ne doprinosi dovoljno dobrotvornom cilju.

Navedeno sugerira kako ženski ispitanici imaju pozitivnije percepcije prema marketingu općeg dobra i poduzećima koja sudjeluju u marketingu općeg dobra u odnosu na muške ispitanike. Navedeni rezultati su u skladu s prijašnjim istraživanjima (Chéron i sur., 2012.; Cui i sur., 2003.; Ross i sur., 1992.; Youn i Kim, 2008.), kao i polaznom pretpostavkom ovog istraživanja.

Tablica 6. Deskriptivna statistika i t-test o statistički značajnim razlikama među ispitanicima ovisno o spolu druga skupina tvrdnji $(\mathrm{n}=395)$

\begin{tabular}{|c|c|c|c|c|c|c|c|}
\hline \multicolumn{2}{|c|}{ Tvrdnja/Spol } & $\mathbf{N}$ & Mean & $\begin{array}{c}\text { Std. } \\
\text { Deviation }\end{array}$ & Std. Error & $t$ & $p$ \\
\hline \multirow{2}{*}{ Tvrdnja 3} & Muško & 100 & 3,72 & 1,016 & 0,102 & \multirow{2}{*}{$-0,13785$} & \multirow{2}{*}{$>0,05$} \\
\hline & Žensko & 295 & 3,74 & 0,964 & 0,056 & & \\
\hline \multirow{2}{*}{ Tvrdnja 6} & Muško & 100 & 3,60 & 1,110 & 0,111 & \multirow{2}{*}{$-0,23989$} & \multirow{2}{*}{$>0,05$} \\
\hline & Žensko & 295 & 3,63 & 1,095 & 0,064 & & \\
\hline \multirow{2}{*}{ Tvrdnja 9} & Muško & 100 & 3,53 & 1,000 & 0,100 & \multirow{2}{*}{$-4,71423$} & \multirow{2}{*}{$<0.05$} \\
\hline & Žensko & 295 & 4,04 & 0,914 & 0,053 & & \\
\hline \multirow{2}{*}{ Tvrdnja 10} & Muško & 100 & 3,37 & 1,089 & 0,109 & \multirow{2}{*}{$-4,96384$} & \multirow{2}{*}{$<0.05$} \\
\hline & Žensko & 295 & 3,95 & 0,980 & 0,057 & & \\
\hline \multirow{2}{*}{ Tvrdnja 11} & Muško & 100 & 2,63 & 1,070 & 0,107 & \multirow{2}{*}{$-2,24441$} & \multirow{2}{*}{$<0.05$} \\
\hline & Žensko & 295 & 2,91 & 1,073 & 0,062 & & \\
\hline \multirow{2}{*}{ Tvrdnja 12} & Muško & 100 & 3,33 & 1,256 & 0,126 & \multirow{2}{*}{0,666064} & \multirow{2}{*}{$>0,05$} \\
\hline & Žensko & 295 & 3,24 & 1,063 & 0,062 & & \\
\hline \multirow{2}{*}{ Tvrdnja 13} & Muško & 100 & 3,04 & 1,163 & 0,116 & \multirow{2}{*}{1,084765} & \multirow{2}{*}{$>0,05$} \\
\hline & Žensko & 295 & 2,90 & 1,117 & 0,065 & & \\
\hline \multirow{2}{*}{ Tvrdnja 15} & Muško & 100 & 2,64 & 1,210 & 0,121 & \multirow{2}{*}{1,508802} & \multirow{2}{*}{$>0,05$} \\
\hline & Žensko & 295 & 2,45 & 1,064 & 0,062 & & \\
\hline \multirow{2}{*}{ Tvrdnja 8} & Muško & 100 & 3,38 & 1,162 & 0,116 & \multirow{2}{*}{2,24771} & \multirow{2}{*}{$<0.05$} \\
\hline & Žensko & 295 & 3,08 & 1,126 & 0,066 & & \\
\hline \multirow{2}{*}{ Tvrdnja 14} & Muško & 100 & 3,40 & 1,279 & 0,128 & \multirow{2}{*}{$-0,77722$} & \multirow{2}{*}{$>0,05$} \\
\hline & Žensko & 295 & 3,51 & 1,181 & 0,069 & & \\
\hline
\end{tabular}

Izvor: istraživanje 
Rezultati provedenih F-testova ukazuju da postoje statistički značajne razlike ovisno o dobi ispitanika za tvrdnje 3 (Marketing općeg dobra je samo način dodatne promocije poduzeća.; $\mathrm{F}=2,747, \mathrm{p}<0,05)$ i 6 (Smatram kako marketing općeg dobra donosi više koristi poduzećima nego neprofitnom partneru.; $\mathrm{F}=3,552, \mathrm{p}<0,05)$, dok kod ostalih tvrdnji nema značajne statističke razlike ovisno o dobi ispitanika. Za tvrdnje 3 i 6 najvišu razinu slaganja s tvrdnjama iskazuju ispitanici koji pripadaju dobnoj skupini od 25-35 godina. Polazna pretpostavka ovog istraživanja - da će mlađi potrošači u većoj mjeri iskazati prihvaćenost marketinga općeg dobra - ovime ne može biti poduprta.

Kada je riječ o razini obrazovanja ispitanika, statistički značajne razlike postoje samo za tvrdnju 6, za koju najnižu razinu slaganja iskazuju ispitanici sa završenim stručnim studijem (Smatram kako marketing općeg dobra donosi više koristi poduzećima nego neprofitnom partneru.; $\mathrm{F}=4,263$, p<0,05), dok u ostalim tvrdnjama nema statistički značajnih razlika među odgovorima ispitanika. Nastavno na ove rezultate, potvrđuje se da razina obrazovanja ispitanika ne utječe na prihvaćenost marketinga općeg dobra.

Što se tiče primanja ispitanika, analiza je pokazala kako ne postoje statistički značajne razlike ovisno o primanjima ispitanika niti za jednu od tvrdnji unutar druge skupine, čime se ne može poduprijeti polazna pretpostavka da će razina primanja utjecati na prihvaćenost marketinga općeg dobra.

\subsubsection{Percipirani utjecaj marketinga općeg dobra na odluku o kupnji}

Rezultati istraživanja pokazuju kako su ispitanici iskazali najveću razinu slaganja s tvrdnjom da su spremni zamijeniti marku proizvoda koju sada koriste za onu koja podupire neku dobrotvornu svrhu, dok je jedina tvrdnja s negativnom razinom slaganja ona o kupovini proizvoda i nakon završetka kampanje. Stoga, ako kupnja proizvoda i nakon završetka kampanje sugerira utjecaj na lojalnost potrošača, rezultati istraživanja sugeriraju kako marketing općeg dobra ne utječe na percipiranu lojalnost marki što je u suprotnosti s nekim prethodno provedenim istraživanjima (Adkins, 2007.; Kotler i Lee, 2009.; van den Brink i sur., 2006.).

Rezultati nadalje pokazuju da se ispitanici blago pozitivno slažu s izjavom da su spremni platiti više za proizvod koji podupire neku dobrotvornu svrhu te da iznos donacije povećava vjerojatnost kupnje proizvoda povezanog s marketingom općeg dobra, kao i da su spremni kupovati taj proizvod za vrijeme trajanja kampanje. Ovi su rezultati u skladu s prethodnim istraživanjima koja sugeriraju kako veći iznos donacije pozitivno utječe na odluku o kupnji (Chang, 2008.; Sinčić Ćorić i sur., 2011.). Detaljni rezultati se nalaze u Tablici 7. 
Tablica 7. Rezultati istraživanja percipiranog utjecaja marketinga općeg dobra na odluku o kupnji (n = 395)

\begin{tabular}{|c|c|c|c|c|}
\hline Tvrdnja & $\begin{array}{l}\text { Prosječna } \\
\text { vrijednost }\end{array}$ & \begin{tabular}{|c|} 
Apsolutna \\
frekvencija \\
odgovora u \\
potpunosti se \\
slažem \\
\end{tabular} & $\begin{array}{c}\text { Apsolutna } \\
\text { frekvencija } \\
\text { odgovora } \\
\text { “uopće se ne } \\
\text { slažem" }\end{array}$ & $\begin{array}{l}\text { Oznaka } \\
\text { tvrdnje }\end{array}$ \\
\hline $\begin{array}{l}\text { Kupovat ću proizvod koji } \\
\text { podupire neku dobrotvornu } \\
\text { svrhu sve dok traje } \\
\text { kampanja. }\end{array}$ & 3,05 & 49 & 48 & „trajanje“ \\
\hline $\begin{array}{l}\text { Što je veći iznos koji ide } \\
\text { dobrotvornom cilju to je veća } \\
\text { vjerojatnost da ću kupiti taj } \\
\text { proizvod. }\end{array}$ & 3,18 & 80 & 50 & ,iznos“" \\
\hline $\begin{array}{l}\text { Spreman sam platiti više za } \\
\text { proizvod koji podupire neku } \\
\text { dobrotvornu svrhu. }\end{array}$ & 3,13 & 63 & 56 & „cijena“ \\
\hline $\begin{array}{l}\text { Spreman sam promijeniti } \\
\text { marku proizvoda koju } \\
\text { trenutno koristim za marku } \\
\text { proizvoda koja podupire } \\
\text { određenu dobrotvornu svrhu } \\
\text { pod uvjetom da zadovoljava } \\
\text { moje potrebe. }\end{array}$ & 3,25 & 80 & 55 & „marka“6 \\
\hline $\begin{array}{l}\text { Kupovat ću proizvode } \\
\text { poduzeća koje sudjeluje u } \\
\text { marketingu općeg dobra i } \\
\text { nakon završetka kampanje }\end{array}$ & 2,89 & 23 & 44 & „završetak“ \\
\hline
\end{tabular}

Izvor: istraživanje

Testom je utvrđeno kako postoje statistički značajne razlike ovisno spolu ispitanika za svaku od tvrdnji unutar skupine. Žene iskazuju višu razinu slaganja sa svim navedenim tvrdnjama, što je u skladu s drugim provedenim istraživanjima (Chéron i sur., 2012.; Cui i sur., 2003.; Ross i sur., 1992.; Youn i Kim, 2008.) (Tablica 8). Ovim je rezultatima još jednom potvrđeno da žene iskazuju veću prihvaćenost marketinga općeg dobra u odnosu na muškarce. 
D. Sinčić Ć́rić, J. Tomić: Utjecaj demografskih obilježja potrošača na prihvaćenost marketinga...

Tablica 8. Deskriptivna statistika i rezultati istraživanja percipiranog utjecaja marketinga općeg dobra na odluku o kupnji ovisno o spolu $(\mathrm{n}=395)$

\begin{tabular}{|c|c|c|c|c|c|c|c|}
\hline \multicolumn{2}{|c|}{ Tvrdnja/Spol } & $\mathbf{N}$ & Mean & $\begin{array}{c}\text { Std. } \\
\text { Deviation }\end{array}$ & $\begin{array}{l}\text { Std. Error } \\
\text { Mean }\end{array}$ & $\mathbf{t}$ & $\mathbf{p}$ \\
\hline \multirow{2}{*}{ „trajanje“ } & Muško & 100 & 2,71 & 1,250 & 0,125 & \multirow{2}{*}{$-3,381$} & \multirow{2}{*}{$<0,05$} \\
\hline & Žensko & 295 & 3,17 & 1,148 & 0,067 & & \\
\hline \multirow{2}{*}{ „,iznos“ } & Muško & 100 & 2,85 & 1,321 & 0,132 & \multirow{2}{*}{$-3,021$} & \multirow{2}{*}{$<0,05$} \\
\hline & Žensko & 295 & 3,30 & 1,269 & 0,074 & & \\
\hline \multirow{2}{*}{ „,cijena“ } & Muško & 100 & 2,58 & 1,232 & 0,123 & \multirow{2}{*}{$-5,164$} & \multirow{2}{*}{$<0,05$} \\
\hline & Žensko & 295 & 3,32 & 1,237 & 0,072 & & \\
\hline \multirow{2}{*}{ „marka“ } & Muško & 100 & 2,88 & 1,313 & 0,131 & \multirow{2}{*}{$-3,305$} & \multirow{2}{*}{$<0,05$} \\
\hline & Žensko & 295 & 3,38 & 1,293 & 0,075 & & \\
\hline \multirow{2}{*}{ „završetak“ } & Muško & 100 & 2,63 & 1,089 & 0,109 & \multirow{2}{*}{$-2,929$} & \multirow{2}{*}{$<0,05$} \\
\hline & Žensko & 295 & 2,98 & 0,998 & 0,058 & & \\
\hline
\end{tabular}

Izvor: istraživanje

Rezultati pokazuju kako postoje statistički značajne razlike ovisno dobi ispitanika samo za tvrdnju ,iznos“ (Što je veći iznos koji ide dobrotvornom cilju to je veća vjerojatnost da ću kupiti taj proizvod; $\mathrm{F}=3,007, \mathrm{p}<0,05)$, pri čemu najveću razinu slaganja s tvrdnjom prosječno iskazuju ispitanici u dobnoj skupini od 25-35 godina. Ovaj nalaz sugerira da veći iznos donacije povećava percipiranu spremnost kupnje najviše kod ove skupine ispitanika. Najnižu razinu slaganja iskazuju stariji ispitanici (od 55 godina naviše). No, općenito, nalazi ne potvrđuju polaznu pretpostavka o utjecaju dobi na prihvaćenost marketinga općeg dobra.

Statističke značajne razlike ovisno o primanjima te razini obrazovanja ispitanika niti za jednu od promatranih tvrdnji nisu utvrđene.

Rezultati istraživanja mogu se povezati i s prethodnim istraživanjem Štulec i sur. (2017), koje je utvrdilo da spol, dob i obrazovanje ispitanika utječu na proces donošenja odluke o kupovini, no ne u svim fazama procesa odlučivanja o kupnji jednako. Utjecaj demografskih obilježja kupaca na njihovo kupovno ponašanje potvrdili su i Anić i sur. (2015), prilikom istraživanja kupovine ekoloških prehrambenih proizvoda, zaključujući kako visina dohotka i dob utječu, dok razina obrazovanja i spol ne utječu na njihovo ponašanje.

\subsection{Ograničenja istraživanja i prijedlozi za buduća istraživanja}

Rezultate dobivene istraživanjem potrebno je tumačiti uzimajući u obzir određena ograničenja: (1) prvo ograničenje proizlazi iz prirode i veličine prigodnog uzorka, kao i (2) njegove strukture. Potom, (3) nezainteresiranost ispitanika za temu, pad koncentracije ili pažnje prilikom ispunjavanja upitnika, kao i (4) potencijalna sklonost ispitanika društveno 
prihvatljivim odgovorima, smanjuju mogućnost generalizacije rezultata za čitavu populaciju.

Buduća istraživanja mogla bi se usmjeriti na analizu utjecaja demografskih obilježja ispitanika na namjeru kupnje i lojalnost potrošača uključenih u program marketinga općeg dobra, primjerice s obzirom na različite kategorije proizvoda. S obzirom na ograničenja koja proizlaze iz uzorka, pri sljedećem bi istraživanju uzorak trebao biti u većoj mjeri reprezentativan za čitavu populaciju. Također, za utvrđivanje preciznijih veza i utjecaja, u budućim istraživanjima mogle bi se koristiti složenije statističke analize.

\section{ZAKLJUČAK}

Učinkovita primjena marketinga općeg dobra ima brojne prednosti za sve uključene strane: (1) poduzeća ostvaruju brojne koristi, poput povećane prodaje, boljeg imidža, diferencijacije i lojalnosti potrošača; (2) neprofitne organizacije kroz program marketinga općeg dobra ostvaruju dodatno financiranje i doseg šire javnosti, dok (3) potrošači dobivaju mogućnost jednostavnim sudjelovanjem pridonijeti dobrobiti zajednice odnosno društva.

Ovo istraživanje je potvrdilo kako spol i dob utječu na percepcije potrošača prema marketingu općeg dobra i percipiranu odluku o kupnji, što je u skladu s ranije provedenim istraživanjima. Također, istraživanje sugerira kako iznos donacije i trajanje kampanje marketinga općeg dobra utječu na percepcije potrošača o samoj kampanji, kao i na odluku o kupnji proizvoda povezanih s društvenim ciljem. Razina obrazovanja i prihodi nisu pokazali statistički značajan utjecaj percepcije ispitanika o marketingu općeg dobra.

Rezultati osiguravaju određenu vrijednost i za marketinške menadžere. Bez obzira na druge moguće utjecaje (poput, primjerice, kulture doniranja, humanosti ili drugih osobina potrošača), pokazuje se da žene u svim pitanjima pokazuju veću prihvaćenost marketinga općeg dobra. U tom smislu, žene su očito prijemčivije za poruke koje se komuniciraju u kampanjama marketinga općeg dobra, te bi one trebale biti primarno ciljno tržište u planiranim kampanjama. Osim toga, žene su (još uvijek) primarni kupci u obitelji, što povećava vjerojatnost da njihova sklonost proizvodima koji podupiru marketing općeg dobra preraste u kupovni odabir.

\section{POPIS LITERATURE}

1. Adkins, S. (1999). Cause related marketing: who cares wins. Butterworth-Heinemann

2. Adkins, S. (2007). Cause related marketing. Routledge.

3. Anić, I. D, Jelenc, L. \& Šebetić, N. (2015). Istraživanje demografskih obilježja i ponašanja kupaca ekoloških prehrambenih proizvoda u Karlovačkoj županiji, Ekonomska misao i praksa, 26(2), 367-388.

4. Barnes, N.G. 2015. Partners in profits: Small businesses move slowly into cause-related marketing. Journal of Small Business Strategy, 9(1), 47-55.

5. Barone, M. J., Miyazaki, A. D., \& Taylor, K. A. (2000). The Influence of Cause-Related Marketing on Consumer Choice: Does One Good Turn Deserve Anot- 
her? Journal of the Academy of Marketing Science, 28(2), 248-262. https://doi. org/10.1177/0092070300282006

6. Bennett, R. (2003). Factors underlying the inclination to donate to particular types of charity. International Journal of Nonprofit and Voluntary Sector Marketing, 8(1), 1229. https://doi.org/10.1002/nvsm.198

7. Berglind, M., \& Nakata, C. (2005). Cause-related marketing: More buck than bang? Business Horizons, 48(5), 443-453. https://doi.org/10.1016/j.bushor.2005.04.008

8. Brunel, F. F., \& Nelson, M. R. (2000). Explaining gendered responses to "help-self" and "help-others" charity ad appeals: The mediating role of world-views. Journal of Advertising, 29(3), 15-28

9. Chaney, I., \& Dolli, N. (2001). Cause-related marketing in New Zealand. International Journal of Nonprofit and Voluntary Sector Marketing, 6(2), May, 156-163. https:// doi.org/10.1002/nvsm.143

10. Chang, C.T. (2008). To donate or not to donate? Product characteristics and framing effects of cause-related marketing on consumer purchase behaviour. Psychology \& Marketing, 25(12), 1089-1110. https://doi.org/10.1002/mar.20255

11. Chéron,E.,Kohlbacher,F., \& Kusuma,K.(2012). The effects of brand-cause fit and campaign duration on consumer perception of cause-related marketing in Japan. Journal of Consumer Marketing, 29(5), 357-368. https://doi.org/10.1108/07363761211247479

12. Chrenka, J., Gutter, M. S., \& Jasper, C. (2003). Gender differences in the decision to give time or money. Consumer Interests Annual, Annual Conference of the American Council on Consumer Interests Volume 40, 1-4.

13. Cone C. (2004). Cone Corporate Citizenship Study: Building Brand Trust. Executive Summary. Research Report. Boston

14. Cui, Y., Trent, E.S., Sullivan, P.M., \& Matiru, G.N. (2003). Cause-related marketing: How generation Y responds. International Journal of Retail \& Distribution, 31(6), 310-320. https://doi.org/10.1108/09590550310476012

15. Dahl, D.W., \& Lavack, A.M. (1995). Cause-related marketing: Impact of size of corporate donation and size of cause-related promotion on consumer perceptions and participation, in Proceedings of the American Marketing Association Winter Educators' Conference, 476-481.

16. Endacott,R.W.J.(2004). Consumers and CRM: A national and global perspective.JournalofConsumer Marketing,21(3),183-189.https://doi.org/10.1108/07363760410534731

17. Farache, F., Perks, K. J., Wanderley, L. S. O., \& Sousa Filho, J. M. D. (2008). Cause related marketing: consumers' perceptions and benefits for profit and non-profits organisations. BAR-Brazilian Administration Review, 5(3), 210-224. https://doi. org/10.1590/S1807-76922008000300004

18. Galan Ladero, M.M., Galera Casquet, C., \& Singh, J. (2015). Understanding factors influencing consumer attitudes toward cause-related marketing. International Journal of Nonprofit and Voluntary Sector Marketing, 20(1), 52-70. https://doi.org/10.1002/nvsm.1517

19. Guerreiro, J., Rita, P., \& Trigueiros, D. (2015). Attention, emotions and cause-related marketing effectiveness. European Journal of Marketing, 49(11/12), 1728-1750. https://doi.org/10.1108/EJM-09-2014-0543 
20. Hajjat, M.M. (2003). Effect of cause-related marketing on attitudes and purchase intentions: The moderating role of cause involvement and donation size. Journal of Nonprofit \& Public Sector Marketing, 11(1), 93-109. https://doi.org/10.1300/ J054v11n01_07

21. Hammad, H., El-Bassiouny, N., Paul, P., \& Mukhopadhyay, K. (2014). Antecedents and consequences of consumers' attitudinal dispositions toward cause-related marketing in Egypt. Journal of Islamic Marketing, 5(3), 414-445. http://dx.doi.org/10.1108/ JIMA-10-2013-0076

22. Harvey, J. (1990). Benefit segmentation for fundraisers. Journal of the Academy of Marketing Science, 18(1), 77-86. https://doi.org/10.1177/009207039001800107

23. Jones, A., \& Posnett, J. (1991). Charitable donations by UK households: evidence from the Family Expenditure Survey. Applied Economics, 23(2), 343-351. https://doi. org/10.1080/00036849100000143

24. Kim, J.E., \& Johnson, K.K. (2013). The impact of moral emotions on cause-related marketing campaigns: A cross-cultural examination. Journal of Business Ethics, 112(1), 79-90. https://doi.org/10.1007/s10551-012-1233-6

25. Kotler, P., \& Lee, N. (2005). Best of breed: When it comes to gaining a market edge while supporting a social cause,"corporate social marketing" leads the pack. Social marketing quarterly, 11(3-4), 91-103. https://doi.org/10.1080/15245000500414480

26. Kotler, P. T., \& Lee, N. R. (2009). Up and out of poverty: The social marketing solution. Pearson Prentice Hall.

27. Lafferty, B. A. (1996). Cause-related marketing: Does the cause make a difference in consumers' attitudes and purchase intentions toward the product?.Working paper, Florida State University, Department of Marketing

28. Lerro, M., Raimondo, M., Stanco, M., Nazzaro, C., \& Marotta, G. (2019). Cause related marketing among millennial consumers: The role of trust and loyalty in the food industry. Sustainability, 11(2), 535. https://doi.org/10.3390/su11020535

29. Lichtenstein, D. R., Drumwright, M. E., \& Braig, B. M. (2004). The effect of corporate social responsibility on customer donations to corporate-supported nonprofits. Journal of marketing, 68(4), 16-32. https://doi.org/10.1509/jmkg.68.4.16.42726

30. Meyer, H. (1999). When the Cause is Just. Journal of Business Strategy, 20(6), 27-31. https://doi.org/10.1108/eb040042

31. Mohr, L. A., Webb, D. J., \& Harris, K. E. (2001). Do consumers expect companies to be socially responsible? The impact of corporate social responsibility on buying behavior. Journal of Consumer affairs, 35(1), 45-72. https://doi.org/10.1111/j.1745-6606.2001. tb00102.x

32. Moosmayer, D.C., \& Fuljahn, A. (2010). Consumer perceptions of cause-related marketing campaigns. Journal of Consumer Marketing, 27(6), 543-549. https://doi. org/10.1108/07363761011078280

33. Nan, X. and Heo, K. (2007) Consumer responses to corporate social responsibility (CSR) initiatives: Examining the role of brand-cause fit in cause-related marketing. Journal of Advertising 36 (2): 63-74. https://doi.org/10.2753/JOA0091-3367360204 
34. Penner, L. A., Dovidio, J. F., Piliavin, J. A., \& Schroeder, D. A. (2005). Prosocial behavior: Multilevel perspectives. Annual Review of Psychology 56, 365-392. https:// doi.org/10.1146/annurev.psych.56.091103.070141

35. Pracejus, J. W., \& Olsen, G. D. (2004). The role of brand/cause fit in the effectiveness of cause-related marketing campaigns. Journal of Business Research, 57(6), 635-640. https://doi.org/10.1016/S0148-2963(02)00306-5

36. Ross III, J.K., Patterson, L.T., \& Stutts, M.A. (1992). Consumer perceptions of organizations that use cause-related marketing. Journal of the Academy of Marketing Science, 20(1), 93-97. https://doi.org/10.1007/BF02723480

37. Roy, D.P., \& Graeff, T.R. (2003). Consumer attitudes toward cause-related marketing activities in professional sports. Sport Marketing Quarterly, 12(3), 163-172.

38. Schlegelmilch, B. B., Love, A., \& Diamantopoulos, A. (1997). Responses to different charity appeals: the impact of donor characteristics on the amount of donations. European Journal of Marketing, 31(8), 548-560.

39. Sinčić Ćorić, D., \& Kurnoga Živadinović, N. (2009). Utjecaj odabranih elemenata marketinga općeg dobra na odabir marke. Tržište, 21(1), 70-79.

40. Sinčić Ćorić, D., Kurnoga Živadinović, N., \& Dropuljić, M. (2011). The effects of cause and donation size of cause-related marketing program on consumers' intention to buy. EFZG working paper series, (08), 1-14.

41. Štulec, I., Petljak, K.,\& Rakarić, J.(2017). Utjecaj demografskih karakteristika potrošača na proces donošenja odluke o kupovini. Ekonomska misao i praksa, 26(1), 381-403.

42. Subrahmanyan, S. (2004). Pricing strategy and practice: Effects of price premium and product type on the choice of cause-related brands: A Singapore perspective. Journal of Product \& Brand Management, 13(2), 116-124. https://doi. org/10.1108/10610420410529744

43. Supphellen, M., \& Nelson, M.R. (2001). Developing, exploring, and validating a typology of private philanthropic decision-making. Journal of Economic Psychology, 22(5), 573-603. https://doi.org/10.1016/S0167-4870(01)00056-3

44. Van den Brink, D., Odekerken-Schröder, G., \& Pauwels, P. (2006). The effect of strategic and tactical cause-related marketing on consumers' brand loyalty. Journal of Consumer Marketing, 23(1), 15-25. https://doi.org/10.1108/07363760610641127

45. Vanhamme, J., Lindgreen, A., Reast, J., \& Van Popering, N. (2012). To do well by doing good: Improving corporate image through cause-related marketing. Journal of Business Ethics, 109(3), 259-274. https://doi.org/10.1007/s10551-011-1134-0

46. Varadarajan, R.P., \& Menon, A. (1988). Cause-related marketing: A co-alignment of marketing strategy and corporate philanthropy. Journal of Marketing, 52(3), 58-74. https://doi.org/10.1177/002224298805200306

47. Webb, D.J., \& Mohr, L.A. (1998). A typology of consumers responses to cause-related marketing: From sceptics to socially concerned. Journal of Public Policy \& Marketing, 17(2), 226-238. https://doi.org/10.1177/074391569801700207

48. Youn, S. \& Kim, H. (2008). Antecedents of consumer attitudes toward cause-related marketing. Journal of Advertising Research, 48(1),123-138. https://doi.org/10.2501/ S0021849908080136 